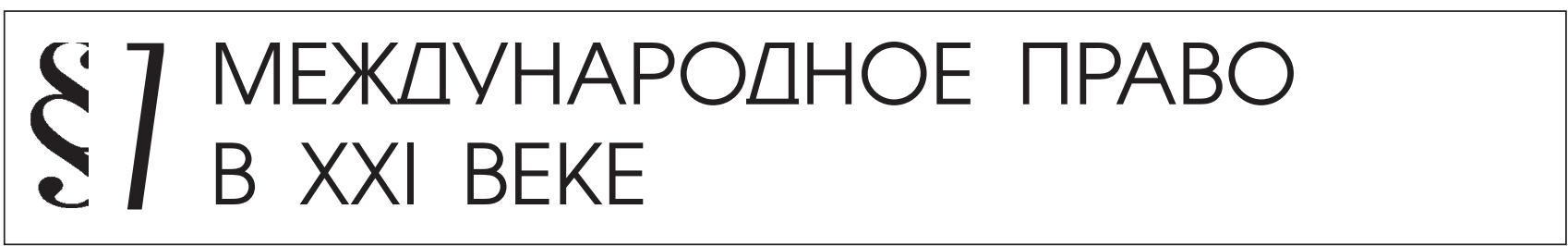

Сазонова К.Л.

\title{
К ВОПРОСУ ОБ ОТВЕТСТВЕННОСТИ ГОСУДАРСТВ ЗА ПРИМЕНЕНИЕ СИЛЫ В СОВРЕМЕННОМ МЕЖДУНАРОДНОМ ПРАВЕ
}

\begin{abstract}
Аннотация: В данной статье рассматривается актуальный вопрос ответственности за применение силь, который является составной частью института ответственности в международном праве. Проблема ответственности вот уже более полувека является одной из самых неурегулированных отраслей права, так как тесно связана с такими дискуссионными правовыми аспектами, как проблема государственного суверенитета и проблемы легитимного и нелегитимного применения силь в международном праве. Автор анализирует основания, влекущие возникновение ответственности, понятие вины, а также различные взгляды теоретиков на проблему ответственности в цуелом. Можно предположить, что проблема кодификации вопроса ответственности в дальнейшем неизбежно повлечет проблему реализации ответственности, так как данный институт балансирует на стыке права и политики. Ответственность за применение силы государствами нуждается в постоянном обсуждении и внимании со стороны научного сообщества, так как именно развитие института ответственности позволило бы «навести порядок» в современных международных отношениях, сократить случаи неправомерного применения силь и обозначить начало нового этапа международного права.
\end{abstract}

Ключевые слова: Юриспруденция, ответственность, сила, право, институт, кодификация, государства, вина, отрасль, проект

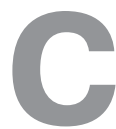

момента принятия Устава Организации Объединенных Наций 1945 г. в международном праве действует принцип неприменения силы. Тем не менее, реалии современных международных отношений таковы, что сила активно применяется и, скорее всего, будет применяться в обозримом будущем. Вторжение войск НАТО в бывшую Югославию, массовые убийства в Руанде, линчевание без суда и следствия ливийским народом своего вождя М. Каддафи, поддержка американскими спецслужбами «цветных» революций на постсоветском пространстве - вот лишь некоторые примеры противоправного поведения государств, которые, безусловно, привлекли внимание международного сообщества в последние десятилетия. Однако можно констатировать, что ответственности за подобные очевидные нарушения международного права государства, их совершившие, не понесли. Причина подобного «безнаказанности» состоит в том, что один из важнейших институтов международного права - институт ответственности государств - по сей день является предметом споров политиков, государственных деятелей и теоретиков международного права. Так, профессор Я. Броунли еще в конце 1970-х гг. отмечал, что даже «терминология, связанная с данным вопросом, находится в хаотическом состоянии - факт, который частично отражает различия во взглядах по существу вопроса» ${ }^{1}$.

Международно-правовые акты второй половины XX в. были призваны минимизировать урон и последствия применения силы. Однако реалии, к сожалению, демонстрируют, что сила продолжает оставаться важнейшим фактором: «сила, и только сила, структурирует человеческое общество - иное дело, что она должна применяться адекватно и пропорционально» ${ }^{2}$. Проблема применения силы сложна сама по себе, несмотря на то, что традиционно «Устав ООН различает законные случаи применения государствами силы в своих международных отношениях (когда применение силы совместимо с целями ООН) и незаконные (когда оно несовместимо с этими целями)», ${ }^{3}$ однако в реальности грань между законным и незаконным применением силы очень тонка.

\footnotetext{
${ }^{1}$ Броунли Я. Международное право, М., 1977. - с. 144.

${ }^{2}$ Малеев Ю.Н. Организация Объединенных Наций и применение вооруженной силы государствами. 60 лет ООН. 50 лет Российской ассоциации содействия ООН. М., из-во РУДН, 2006. - с.99.
}

${ }^{3}$ Котляр В.С. Международное право и современные стратегические концепции США и НАТО. М., 2008. - с. 125. 


\section{Право и политика 6 (162) 2013}

Развитие международного гуманитарного права, институтов защиты прав и свобод человека, миротворческой деятельности ООН, безусловно, способствовали тому, что применение силы стало процессом, который если и допускается в случаях, запрещенных Уставом $\mathrm{OOH}$, то, по крайней мере, осуждается международным сообществом, однако один из важнейших институтов современного международного права, непосредственно связанный с вопросом применения силы, по-прежнему не имеет полноценной нормативно-правовой базы. Речь идет об институте ответственности за применение силы государствами. Необходимо отметить, что, несмотря на очевидную актуальность, данная тема не разработана в достаточной степени по причине значительной политизированности любых вопросов, связанных с ответственностью. Институт ответственности за применение силы является составной частью института ответственности в международном праве, который также кодифицирован и систематизирован далеко не в полной мере.

Еще в 1973 г. советский ученый Курис М.П. «Понятие международно-правовой ответственности относится к тем вопросам, которые до сих пор еще не получили достаточной разработки в международном праве». ${ }^{4}$ Можно констатировать, что и сорок лет спустя ситуация не сильно изменилась, именно поэтому принятие Комиссией международного права ООН в 2001 г. проекта статей об ответственности государств профессор И.И. Лукашук назвал «наступлением нового этапа в развитии международного права» 5 .

Важнейшим вопросом ответственности государств является вопрос об основаниях наступления ответственности. Ответственность государств может наступать за совершение международного правонарушения, либо за причинение ущерба в результате определенной международно-правовой деятельности, например, в международном космическом, морском, экологическом праве. Так, например, об ответственности государств упоминается в Договоре о принципах деятельности государств по исследованию и использованию космического пространства, включая Луну и другие небесные тела 1967 г., Конвенции о международной ответственности за ущерб, причиненный космическими объектами 1972 г., Венской конвенции о гражданской ответственности за ядерный ущерб 1964 г., Конвенции по морскому праву 1982 г., однако данные договоры не связаны с непосредственной кодификацией общих норм об ответственности государств. Кроме того, некоторые нормы, относящихся к ответственности, содержит право международных договоров, например прекращение

${ }^{4}$ Курис П.М. Международные правонарушения и ответственность государств. Вильнюс, 1973.- с. 15.

5 Лукашук И.И. Право международной ответственности , М., 2004. - c. 67. нарушенного договора, признание ничтожным договора, навязанного силой. Однако наиболее актуальным и дискуссионным сегодня является вопрос об ответственности государств за применение силы. В современном международном праве отсутствует единство классификации института ответственности за применение силы. По моему мнению, институт ответственности государств за применение силы можно разделить на две категории, а именно: ответственность государств за применение силы по отношению к другим государствам и ответственность государств за применение силы по отношению к гражданам внутри данного государства. Первая категория ответственности в научной литературе иногда именуется «ответственность государств за международные преступления». Вторая категория ответственности также иногда называется «ответственность за нарушения прав и свобод человека». В любом случае, базовое деление ответственности основано на территориальном принципе - то есть либо преступление, порождающее ответственность, совершается внутри государства, либо государство действует за пределами своей территории. Важнейшими проблемами, связанными с вопросом ответственности государств, являются проблема государственного суверенитета и проблема применения силы в международном праве.

Основной проблемой института ответственности государств является то, что данная отрасль почти не кодифицирована. С 1953 г. Комиссия международного права ООН занимается проблемой кодификации отрасли, единственным нормативным документом которой является принятый в 2001 г. проект статей «Об ответственности государств», который, к сожалению, так и является проектом по состоянию на сегодняшний день, хотя представляет собой плод многолетнего обобщения норм обычного права: «Проект разрабатывался Комиссией свыше четверти века. В этом процессе принимал участие широкий круг правительств, представлявших свои замечания на подготовленные Комиссией статьи, которые тщательно учитывались. Дело было непростым, поскольку позиции правительств существенно расходились. ${ }^{6}$

Обобщая нормы обычного международного права, можно выделить две базовые формы, в которых реализуется ответственность государств: материальная в виде компенсаций, реституций, субституций и репараций), и нематериальная (которую также называют политической и моральной ответственностью) в виде реторсий, репрессалий, сатисфакции, ресторации, приостановление членства или исключение из международной организации, а также применение санкций как «мер военно-политического характера, которые представляют собою своеобразное на6 Лукашук И.И. Право международной ответственности . М.,
2004. - с. 64. 
казание за совершение международных преступлений»7. Именно по причине преобладания обычных норм в данной отрасли права, среди отечественных ученых присутствуют споры относительно самостоятельности данной отрасли современного международного права. Например, профессор И.И. Лукашук считал, что уже вполне можно говорить о сложившейся самостоятельной отрасли - праве международной ответственности ${ }^{8}$, в то время как профессор К.А. Бекяшев полагает, что отрасль международного публичного права находится пока на стадии формирования, так как «Проект статей ответственности государств за международно-противоправные деяния» еще не получил статуса международного договора 9 .

В научном сообществе по-прежнему ведутся дискуссии относительно того, что, собственно, понимается под «применением силы» в современном международном праве? Только ли непосредственно использование вооруженных сил и всего, что попадает под определение агрессии по резолюции Генеральной Ассамблеи ООН от 14 декабря 1974 года ${ }^{10}$, или же, в свете последних событий на Ближнем Востоке, применением силы можно также считать существование и деятельность диктаторских режимов?

Применение государством силы по отношению к гражданам внутри данного государства является одним из самых щекотливых и дискуссионных аспектов современного международного права. С одной стороны, государство как носитель суверенитета вправе самостоятельно устанавливать политический режим, с другой стороны, такие важные документы, касающиеся прав и свобод человека, как Всеобщая декларация прав человека 1948 г., Конвенция по предупреждению и наказанию преступления геноцида 1948 г., Международная конвенция о ликвидации всех форм расовой дискриминации 1965 г., Международный пакт об гражданских и политических правах и Международный пакт об экономических, социальных и культурных правах 1966 г., Конвенция о неприменимости срока давности к военным преступлениям и преступлениям против человечности 1968 г.. Конвенция о пресечении преступления апартеида и наказании за него 1973 г., Конвенция о правах ребенка 1989 г. и прочие международно-правовые договоры и конвенции были призваны существенно сократить случаи массовых грубых нарушений прав человека, а также ограничить методы

\footnotetext{
${ }^{7}$ Котляров И.И. Международное гуманитарное право. М. 2003.c. 248 .

8 Лукашук И.И. Право международной ответственности. М., 2004. - c. 65 .

${ }^{9}$ Бекямев К.А. Международное право, М., 2005. - с. 192.

${ }^{10}$ Резолюция «Определение агрессии» Генеральной Ассамблеи ООН 3314 (XXIX) от 14 декабря 1974 г. http://www.un.org/ru/ documents/decl_conv/conventions/aggression.shtml
}

реализации авторитарного и тоталитарного режимов. Однако крайне сложно определить, в каких случаях нарушения прав человека возможно внешнее вмешательство со стороны международного сообщества, так как в Уставе ООН принцип невмешательства сформулирован как «невмешательство в дела, по существу входящие во внутреннюю компетенцию государства», а понятие дел, относящихся к внутренней компетенции, по-прежнему остается прерогативой суверенного государства.

Сложным и неурегулированным остается вопрос о государстве как субъекте международно-правовой ответственности, так как государство в любом случае действует с помощью своих органов, и любое противоправное действие или бездействие совершается государственными органами или должностными лицами. Из-за неразрывной связи государства, его органов и его должностных лиц можно констатировать несовпадение субъекта правонарушения и субъекта ответственности, что и составляет специфику права международной ответственности государств. Важным и дискуссионным среди юристов-международников также остается вопрос о вине как составляющей международного правонарушения, совершаемого государством. Согласно проекту статей об ответственности государств, Комиссия международного права не включила в проект статей элемент вины государства как необходимый признак правонарушения.

Для преследования лиц, ответственных за геноцид, преступления против человечности и военные преступления геноцид, в 2002 г. учрежден Международный уголовный суд в Гааге. Идея, берущая начало в протоколах Нюрнбергского трибунала, состоит в том, что «преступления против международного права совершаются людьми, а не абстрактными существами, и положения международного права могут применяться только путем наказания физических лиц, которые совершают такие преступления». ${ }^{11}$ Однако, во-первых, в компетенцию Международного уголовного суда не включено преступление агрессии, а во-вторых, целый ряд государств не ратифицировал Римский Статут Международного суда, причем среди этих государств такие важнейшие акторы современных международных отношений, как США, Израиль, Иран, Китай, Индия, Российская Федерация. Некоторые государства в качестве обоснования своей позиции приводят довод о том, что сама идея международного уголовного суда ограничивает суверенитет государств. Собственно, из-за этого институт международной ответственности и «буксует» вот уже более полувека. Кроме того, в современном международном праве, как и в любом праве

\footnotetext{
${ }^{11}$ International Military Tribunal (Nuremberg), Judgment and Sentences, October 1, 1946. P. 221. http://werle.rewi.hu-berlin.de/IMTJudgment.pdf
} 


\section{Право и политика $6(162) \cdot 2013$}

вообще, существует «существенный разрыв между правотворчеством и правореализацией» ${ }^{12}$.

Таким образом, выведение института ответственности государств за применение силы на качественно новый уровень кодификации требует значительных изменений парадигмы современного международного права и международных отношений, которое должно сопровождаться усилением роли международных организаций, прежде всего Организации Объединенных Наций, повышением взаимодействия специалистов в области международного права из разных стран, выработки новых подходов к проблеме международно-правовой ответственности.

\section{Библиография:}

1. Бекяшев К.А. Международное право, М., 2005.

2. Броунли Я. Международное право, М., 1977.

3. Котляр В.С. Международное право и современные стратегические концепции США и НАТО. М., 2008.

4. Котляров И.И. Международное гуманитарное право. М. 2003.

5. Курис П.М. Международные правонарушения и ответственность государств. Вильнюс, 1973.

6. Лукашук И.И. Право международной ответственности. М., 2004.

7. Лукашук И.И. Концепция права международной ответственности // Государство и право. М., 2003. №4.

8. Малеев Ю.Н. Организация Объединенных Наций и применение вооруженной силы государствами.
60 лет ООН. 50 лет Российской ассоциации содействия ООН. М., из-во РУДН, 2006.

9. Резолюция «Определение агрессии» Генеральной Ассамблеи ООН 3314 (XXIX) от 14 декабря 1974 г. http://www.un.org/ru/documents/decl_conv/conventions/ aggression.shtml

10. International Military Tribunal (Nuremberg), Judgment and Sentences, October 1, 1946. http://werle.rewi.huberlin.de/IMTJudgment.pdf

\section{References (transliteration):}

1. Bekyashev K.A. Mezhdunarodnoe pravo, M., 2005.

2. Brounli Ya. Mezhdunarodnoe pravo, M., 1977.

3. Kotlyar V.S. Mezhdunarodnoe pravo i sovremennye strategicheskie koncepcii SShA i NATO. M., 2008.

4. Kotlyarov I.I. Mezhdunarodnoe gumanitarnoe pravo. M. 2003.

5. Kuris P.M. Mezhdunarodnye pravonarusheniya i otvetstvennost' gosudarstv. Vil'nyus, 1973.

6. Lukashuk I.I. Pravo mezhdunarodnoy otvetstvennosti. M., 2004.

7. Lukashuk I.I. Koncepciya prava mezhdunarodnoy otvetstvennosti // Gosudarstvo i pravo. M., 2003. №4.

8. Maleev Yu.N. Organizaciya Ob'edinennyh Naciy i primenenie vooruzhennoy sily gosudarstvami. 60 let OON. 50 let Rossiyskoy associacii sodeystviya OON. M., iz-vo RUDN, 2006.

12 Лукашук И.И. Концепция права международной ответственности // Государство и право. М., 2003. №4. - с.79-87. 